\title{
Thai Learners' Linguistic Needs and Language Skills: Implications for Curriculum Development
}

\author{
Mark B. Ulla \\ Walailak University Language Institute, Walailak University, Thailand, \\ mark.ulla1985@gmail.com \\ Duangkamon Winitkun \\ King Mongkut's University of Technology Thonburi, Thailand, \\ duangkamon.w@gmail.com
}

\begin{abstract}
Learners' success in language learning always has implications for curriculum and instruction. Thus, it is important to take into account the kinds of learning experiences that these learners will find helpful in learning English as a foreign language; and, highlight them when planning a curriculum and adapting classroom activities. This study, with 72 first year engineering students, 3 English for Specific Purposes (ESP) teachers of King Mongkut's University of Technology Thonburi (KMUTT) Ratchaburi, and 3 other stakeholders as respondents, aimed to identify the Thai engineering students' linguistic needs and the language skills needed for them to get a job in the future. It also assessed whether the linguistic needs and the language skills required for the students were addressed in the curriculum. Methods used in this study were modified questionnaire, focus groups and semistructured individual interviews. Findings revealed that students wanted to go abroad and to be successful in their future careers; thus, considered speaking as the most important skill to be developed and should be emphasized in their English classes. Students preferred to learn through engaging classroom activities and strategies, exposure to the language, and use of technology in the classroom. However, the ESP curriculum did not provide these linguistic needs and language skills.
\end{abstract}

Keywords: EFL learners, ESP curriculum, needs analysis, linguistic needs, language skills

\section{INTRODUCTION}

Needs analysis studies have been going on in education since the 70's as a guide to develop and design an English for specific purposes curriculum. The works of Munby (1978), Hutchinson and Waters (1987), Dudley-Evans and St. John, (1998), Benesch

Citation: Ulla, M. B., \& Winitkun, D. (2017). Thai Learners' Linguistic Needs and Language Skills: Implications for Curriculum Development. International Journal of Instruction, 10(4), 203-220. https://doi.org/10.12973/iji.2017.10412a 
(2001), and Belcher (2006) which presented arguments and findings about the importance of doing a needs analysis for an ESP/EAP curriculum served as the foundation in many research studies and in the literature on needs assessment and curriculum planning. Hence, key points as to the importance of needs analysis can be taken from the literature. For example, Lekatompessy (2010) stated that, to improve the learners' learning, their learning needs should be considered. In other words, curriculum developers should gather as much information as possible about the needs of their learners since developing a good curriculum prioritizes and looks into the appropriate learning needs and interests of the learners rather than the content that they would be learning. Sothan (2015) also stated that, without conducting a needs analysis for the students before planning a curriculum, this would result in ineffective course programs. Thus, the importance of a needs analysis is indispensable in curriculum development as it not only identifies the needs of the students but also discovers the ways to address their needs and the skills needed to be taught for their future careers. However, this does not seem to be the case in most universities in Thailand and in the ASEAN region; since, most of their existing curriculum were adapted and were not designed and prepared for the Thai students and for other EFL learners in the region.

In the case of King Mongkut University of Technology Thonburi (KMUTT), Ratchaburi, Thailand, the curriculum is adapted from the School of Liberal Arts in KMUTT- Bangmod, the main campus. Even if the courses and the curriculum of General English, Technical English, and English for Workplace Communication in KMUTT-Ratchaburi were already developed and used for these students in the previous semesters, they were not yet examined whether they meet the linguistics needs and the language skills required of the students to prepare them for their future career. Thus, this present study aimed to identify the linguistic needs and the language skills of the Thai engineering students to become successful engineers in the future. These linguistic needs and language skills would then be matched with the existing ESP curriculum whether it meets and caters these needs. The findings will become the basis for ESP teachers, curriculum developers, and language policy makers in Thailand and in the whole ASEAN region to develop a curriculum that is more effective and appropriate for the EFL students; preparing them to be competent engineers in the future.

\section{LITERATURE REVIEW}

\section{Language Needs Analysis in ESP/EAP Curriculum Development}

Many scholars (Dudley-Evans \& St. John, 1998; Hutchinson, \& Waters, 1987; Munby, 1978) have recognized the significance of doing a needs analysis of the students prior to creating and developing an ESP/EAP curriculum. In fact, according to Lekatompessy (2010), as early as the 1960 s to 1970 s, needs analysis was already introduced into language teaching through the ESP movement. However, it has been conducted informally by teachers who wanted to assess what language points their students needed to learn. Its importance has also been considered by some stakeholders (schools' heads, ESP/EAP teachers, program coordinators) since through this, learners develop appropriate English skills that they need in order to cope with the demands in their workplace in the future. 
Several definitions of needs analysis and its importance to curriculum can be taken from the literature. For example, Chegeni and Chegeni, (2013) defined language needs analysis/assessment as vital for designing an ESP course program. Likewise, UNESCO (2016) stated that, through a needs analysis learners would be able to feel ownership of the curriculum as this is designed for them. It can also increase the learners' confidence, and motivation to learn the target language skills. Paci (2013) also mentioned that the purpose of a needs analysis is for the EAP/ESP course instructors to know more about their students' preference in language learning. In this way, instructors can design and prepare materials that would suit their learners' abilities. However, Hutchinson and Waters (1987) emphasized that a needs analysis is a complex process; therefore, a curriculum developer has to analyze and consider both the students' required language skills in order to perform a specific task in the target situation, and their language learning preferences. They called this target needs analysis and learning needs analysis. Historically, it was in Munby's Communicative Syllabus Design (1978) that the term "target needs analysis" was acknowledged. In this book, Munby presented a complete approach towards identifying target situation needs for the students. He named this model "Communicative Needs Processor (CNP)" that made him and this model become the basis for further studies of needs analysis, including Hutchinson and Waters (1987).

Admittedly, in English for specific purposes/academic purposes, needs analysis has become the most important factor in the curriculum. In fact, Dudley-Evans and St. John (1998) said that needs analysis is the foundation of ESP where its result is used to design a learner-centered curriculum. Munby (1978) stated that the ESP syllabus should always be based on the needs of the learners before it is implemented. However, Benesch (2001) did not agree with the term "needs analysis" for the students for it is inappropriate in education. She said that the term implied both psychological and biological needs of the learners. Because of this, she replaced the term "needs analysis" with "rights analysis". Nevertheless, she agreed with the idea that rights analysis should be performed with the learners in EAP. Thus, needs analysis in language teaching and learning has since then become popular as it identifies the linguistics backgrounds of the learners from which a curriculum is developed.

Realizing the importance of needs analysis in language teaching, a number of previous studies (Bada \& Okan, 2000; Balint, 2004; Boroujeni \& Fard, 2013; Chegeni \& Chegeni, 2013; Kaewpet, 2009; Lekatompessy, 2010; Lin, J. et al. 2014; Paci, 2013; Qiu, et. al, 2014; Songhori, 2008; Takahashi, et.al, 2013) made use of the process to design and develop an appropriate curriculum that meets the learners' needs. Although these studies had a different focus, respondents, and research contexts, almost all of them presented the idea that, in assessing the needs of the learners, the potential skills and strategies of both teachers and the students can be discovered. Bada \& Okan (2000) emphasized that when ESP course instructors are familiar with their learners' language abilities and learning needs, success in language teaching and learning can be achieved. Through this, needs analysis has become the basis for all policy makers and educators to develop and design a curriculum that fits the learners' needs. 
However, according to Hutchinson and Waters (1987), needs analysis is a complex process and so is curriculum design (Paci, 2013). Johns (1991), as cited by Lekatompessy (2010), stated that, since needs analysis is the basis of planning a curriculum and other ESP learning materials, it should be conducted first before anything else. Through a needs analysis, it identifies whether or not the curriculum that is being prepared for the students caters and satisfies their learning needs. This idea has been supported by Chegeni and Chegeni (2013) saying that, indeed needs analysis should be made first before the syllabus is developed for teaching as part of the development of the curriculum. Thus, Kaewpet (2009) stated that, no ESP courses should be conducted without needs analysis, neither formal nor informal. The reason for this is that without needs analysis, the specific needs of the learners, and the required skills that they ought to possess, will not be catered to. Good curriculum is always a reflection of good education, thus needs analysis is very important in curriculum development as the knowledge and skills of the learners are always shaped and prepared in the school, preparing them to become well-equipped with the abilities and skills needed for their job or for pursuing higher education.

\section{Related Studies on Curriculum Development through Needs Analysis}

There has been a number of previous studies that dealt with the language learners' needs analysis in order to develop a curriculum. Some studies that were reviewed in this present study, although they differed in some contexts, they recognized the importance of a needs analysis towards curriculum development. For example, Soruc (2012) made an investigation on the role of needs analysis in an English preparatory school in Istanbul and suggested new ways and rationale for making curricular decisions. The study revealed that needs analysis plays an important role in making curricular decisions or renewing language programs.

Qiu, et. al, (2014) conducted a study on needs analysis and curriculum development of vocational Chinese for non-Chinese speaking (NCS) students. Their findings revealed that students' Chinese proficiency varies, and their general Chinese literacy is insufficient to adapt to mainstream classrooms and obtain recognized Chinese proficiency qualifications (e.g. The Hong Kong Diploma of Secondary Education HKDSE). The researchers, based on the results of their study, moved on to syllabus and materials development to address the identified learning needs of the students.

Paci (2013) conducted the same study on the students of the Polytechnic University of Tirana (PUT), Albania. Her findings revealed that the students were not only heterogeneous in their linguistic needs but also in the occupational goals, wants, motivation, learning styles and learning strategies. She then suggested that there should be a developed curriculum which takes into account not only the heterogeneity but also the students' needs.

Another study which was conducted by Boroujeni \& Fard (2013) on needs analysis, concentrated on ESP course for the adoption of communicative language teaching. Their findings revealed that students' learning needs and styles supported the adoption of Communicative Language Teaching and Method. 
On a local context, a study on needs analysis conducted by Kaewpet (2009) presented a framework for the ESP needs of Thai engineering students who would study ESP in an English as a Foreign Language (EFL) environment. The researcher reported that the framework thoroughly examined existing knowledge, making it a potentially suitable for use in other ESP, EFL and ELT contexts.

The works of Bada \& Okan (2000); and Boroujeni \& Fard (2013) as cited in the literature were among the primary sources of this present study as their survey questionnaires were adapted, modified, and used for this research. However, the mentioned studies neither dealt with EFL engineering students nor involved other stakeholders as participants of the study. A study which is closely related with the present research was from Kaewpet (2009); but, the researcher only presented an ESP framework for the Thai engineering students. It failed to identify the Thai engineering linguistic needs and language skills required of them and their implication towards the ESP curriculum development. Thus, it is the purpose of this study to determine the students' language learning needs and their future job's required language skills and their implications towards the development of an ESP curriculum.

\section{METHOD}

The present study has adapted the qualitative-descriptive nature of research. It is qualitative as it makes use of a survey questionnaire, a focus group, and an individual interview to reveal the target audience's range of behavior and the perceptions that drive it with reference to specific topics or issues. It uses in-depth studies of small groups of people to guide and support the construction of hypotheses. Thus, the results of qualitative research are descriptive rather than predictive (QRCA, 2017). However, simple frequency count and percentage distribution were also used to describe the quantitative nature of the study. The analysis of the data came from the three research tools employed in the study; questionnaire, focus groups, and classroom observation.

\section{Respondents}

Out of 133 students who enrolled in LNG102 Technical English course, only 72 (48 males, 24 females) were taken as participants of the study. This is a purposive sampling as these students belonged to the five out of nine classes of Technical English taught by the researchers. These students were in their second semester of their first year taking up engineering courses in KMUTT-Ratchaburi.

Likewise, three stakeholders (the dean of the engineering program, the human resource personnel of a telecommunication company, and a professional civil engineer) were interviewed as to the language skills that are required of an engineer applicant in order to become a successful engineer.

Also, three ESP course instructors (all females) whose teaching experience ranged from 2 to 10 years, were interviewed as to the content of the ESP curriculum; its structure, and design, its textbook, and other materials used in their classes. This was done to get the teachers' perception and evaluation of the existing ESP course. 
For research ethical considerations, a letter of permission to conduct the study in KMUTT-Ratchaburi was made and forwarded for approval to the office of the VicePresident of the University. Having granted the permission, the researchers purposively selected the English classes and students as respondents of the study. The respondents were informed about the conduct of the study, its research objectives, and that all the personal information from them would be treated with utmost confidentiality.

\section{Instruments}

\section{The questionnaire}

In this study, the questionnaire, which was written in the English language (adapted from Bada and Okan, 2000; Boroujeni \& Fard, 2013) was the primary instrument to get the data on students' learning needs. The reason why the researchers adapted the questionnaire is its validity and reliability since the questionnaire has already been validated and used by a number of researchers. The questionnaire, which makes use of a likert scale, consisted of items on which the respondents have to choose with regards to their language learning needs.

The focus-group and the individual interview

To verify and support some items in the questionnaire, a focus group discussion was done in different time and day since the students had to attend different classes. This was employed after the questionnaire survey was completed in order to probe into the details of students' needs analysis. There were 5 focus groups, which consisted of 14-15 student-respondents, conducted and each lasted for about 40 minutes. The discussion, which was done in the local language, was focused on the respondents' English language background and learning needs. The discussion was then transcribed and translated to English.

Furthermore, three stakeholders were individually interviewed to probe into the details of the required language skills that the engineering students should have in order to get a job in the future. The interview took three days in total and each lasted for about 45 minutes. Questions that focused on the required language skills needed to perform the usual language tasks in and out of the office were asked and noted during the interview.

Lastly, three ESP course instructors were also interviewed to identify their assessment and perception on the existing ESP course. The interview was focused on whether the curriculum meets and caters the linguistic needs and language skills of their students in order to perform the tasks needed in their future professions.

\section{Procedure}

After analyzing the returned questionnaires and transcribing the focus groups, and individual interviews, the researchers proceeded to look at and examine the ESP syllabus (Technical English) to determine if the linguistic needs of the students and the required language skills needed to do the job in the future were met and addressed. The researchers, in looking at the syllabus, focused only on the textbook chapters which were included in the syllabus. The language contents, language functions, and language use from the textbook chapters were matched with the questionnaire and interview results. 


\section{FINDINGS}

Based on the data gathered from the questionnaire, the language learning needs of the respondents were revealed in a frequency count and percentage shown in the tables below. For analysis and presentation purposes, only the items which have higher frequency count and percentage are shown.

\section{The Questionnaire}

Table 1

The frequency and percentage distribution of the respondents' language learning needs

\begin{tabular}{lll}
\hline Questions & Frequency & Percentage \\
\hline $\begin{array}{l}\text { 1.Why do you need to study English? } \\
\text { Success for future profession and go abroad }\end{array}$ & 47 & $65 \%$ \\
\hline $\begin{array}{l}\text { 2.Which skills do you want to be emphasized more in your English classes; } \\
\text { Speaking }\end{array}$ & 26 & $36 \%$ \\
\hline $\begin{array}{l}\text { 3.What skills do you want to develop more? } \\
\text { Speaking }\end{array}$ & 45 & $63 \%$ \\
\hline $\begin{array}{l}\text { 4.In the class, how do you like to be grouped? } \\
\text { In small groups }\end{array}$ & 50 & $70 \%$ \\
\hline $\begin{array}{l}\text { 5.How do you want to practice your English? } \\
\text { Talking to people in English }\end{array}$ & 66 & $92 \%$ \\
\hline $\begin{array}{l}\text { 6.When you speak English, how do you want to be corrected? } \\
\text { Later, at the end of the activity, in front of everyone }\end{array}$ & 31 & $46 \%$ \\
\hline 7. Do you like learning from, & 68 \\
\hline a. television/video/films? & $94 \%$ \\
\hline b. radio? & 46 & $74 \%$ \\
\hline c. audio cd files? & 51 & $57 \%$ \\
\hline d. written material (workbooks, modules, course books)? & 40 & $53 \%$ \\
\hline e. the blackboard? & 37 & $92 \%$ \\
\hline f. pictures/posters? & 55 & $70 \%$ \\
\hline a. Role play? & 36 & $53 \%$ \\
\hline b. Language games? & 62 & $89 \%$ \\
\hline c. Songs? & 65 & $90 \%$ \\
\hline d. Talking with and listening to other students? & 64 & $90 \%$ \\
\hline e. Memorizing conversations/dialogues? & 41 & $60 \%$ \\
\hline f. Getting information from guest speakers? & 55 & $80 \%$ \\
\hline g. Going on a field trip? & 69 & $96 \%$ \\
\hline h. Writing a learning diary? & 20 & $29 \%$ \\
\hline
\end{tabular}

It can be gleaned from the table that the students acknowledged the importance of learning the English language for their future career. This data was manifested as most of the students rated "success for future profession and to go abroad" as their choice when asked about the reason why they need to study English. Furthermore, the studentrespondents considered speaking, as one of the most important skills to be developed and to be emphasized in their English class.

The data also revealed that the respondents preferred to learn in small groups whenever they have an activity in their English class and to practice their English skills with people outside of the classroom. However according to the respondents, whenever they 
commit mistakes in using English, they would like to be corrected later, at the end of the activity by their teacher.

When it comes to modes of learning, the respondents preferred to learn through television, video and films in the class. They also stated that they like to be exposed to people who speak English in order to enhance their speaking skills. They suggested that an educational trip is one of the methods they feel helpful towards their learning of the language.

\section{Focus groups findings}

As foreign language speakers of the English language, the respondents believed that having a good command of English would mean an easy way for them to get a good job and to go abroad. However, when they were asked about how they should learn the English language in their own classrooms, they revealed that they would like it to be engaging through various language activities and games. According to them, most of the time in their language classes, they were just made to do the work based on the lesson they had on their textbook; and, there were little opportunities on interactive and engaging activities in the classroom. Thus, role plays, games, simulations, watching English video clips, listening to English audio-cds, and small and big group activities were the learning experiences that they wanted to be employed in their own classrooms. More importantly, they stated that they wanted to learn and improve specifically their speaking and listening skills to become successful engineers in the future.

\section{Interview findings}

Based on the individual interview, the three stakeholders had given the following language tasks that are usually done in and out of the office;
a. Writing proposals, and reports
b. Making presentations
c. Reading and interpreting tables and graphs
d. Answering and making phone calls
e. Meeting clients/customers
f. Reading reports, proposals, and memos
g. Doing research

According to the dean of the engineering program, engineering students should be able to acquire a good proficiency in all four skills, eg, reading, listening, writing, and speaking as these are important and are needed in the workplace. Likewise, the HR personnel in one of the telecommunication companies in Thailand stated that talking to the customers, meeting clients, making and answering phone calls, and making presentations are the basic tasks that employees performed almost every day. Thus, she said further that being good in communicating people especially using the English language is a must requirement for the job. Hence, employees must be able to express their ideas and convince people about their services. Without or lack of communication skills often result to job failure. This is also supported by the professional civil engineer who stated that dealing with people is the usual routine of an engineer. He further said that an engineer should know how and when to present and express ideas in the group 
and must know how to deal with it. According to him, working is not just about the professions, it is about people.

Likewise, the three technical English course instructors when they were interviewed on what they thought about the existing technical English curriculum, admitted that the curriculum did not address much the needs of the learners. They revealed that there was an overlapping of the language contents and functions between the General English (LNG 101) and the Technical English (LNG 102), both the textbooks and their syllabi. General English focuses on the basic knowledge, skills, and functions of the English language. Technical English, on the other hand, still focuses on the basic grammar points based on the textbook used in the classroom. This includes articles, subject pronouns, irregular plural nouns and etc. which should be completely taught and reviewed in the General English. One of the course instructors stated that, Technical English should focus on the skills of writing technical papers, reports, and presentation as these are the skills needed by the students in their future career. However, teachers revealed that they were just following the course program from School of Liberal Arts (SOLA) in KMUTT-Bangmod, the main campus as KMUTT-Ratchaburi is only an extension campus. Hence, any decision to make with regards to changing the curriculum should be approved by the SOLA. They also revealed that writing technical reports, and other technical papers, and doing presentations might be too difficult for their students' linguistic level. However, they stated that developing a curriculum on Technical English that would match and cater the linguistic needs of the engineering students should be considered carefully.

Below is the comparative summary of the students' learning needs and the present curriculum,

Table 2

The comparative significant summary findings of the students' learning needs and what the present curriculum provides and does not provide

\begin{tabular}{ll}
\hline Students' Learning Needs & $\begin{array}{l}\text { What the existing curriculum provides/does not } \\
\text { provide }\end{array}$ \\
\hline $\begin{array}{l}\text { 1. Be successful in the future career } \\
\text { and go aboard. }\end{array}$ & $\begin{array}{l}\text { Basic grammar and technical vocabulary (course } \\
\text { book) are being presented in the course book. }\end{array}$ \\
\hline $\begin{array}{l}\text { 2. Improve speaking skills. } \\
\text { There is no proper model of English speaking } \\
\text { teacher. English is not used as medium of instruction. }\end{array}$ \\
$\begin{array}{ll}\text { 3.Improve listening and taking notes } \\
\text { skills }\end{array}$ & $\begin{array}{l}\text { It may/may not be provided. It depends on the lessons } \\
\text { (course book) }\end{array}$ \\
$\begin{array}{l}\text { 4.Engage to some authentic tasks in } \\
\text { the classroom }\end{array}$ & $\begin{array}{l}\text { There is a course book and it depends on the lecturer } \\
\text { whether he/she provides real-world activities. }\end{array}$ \\
\hline $\begin{array}{l}\text { 5.Go on a field trip } \\
\text { (plantation/laboratory/factory }\end{array}$ & $\begin{array}{l}\text { None } \\
\text { 6.Want to have foreign lecturer/s }\end{array}$ \\
\hline 7.Technology in the classroom & $\begin{array}{l}\text { None } \\
\text { projector, speaker, microphone, air-conditioned, and } \\
\text { white boards. }\end{array}$ \\
\hline
\end{tabular}


Based on the comparative findings whether the existing curriculum provides the language needs of the students as presented in table 1, it can be said that the students' needs were not addressed. For example, the need of the students to improve their speaking skills was not emphasized in the curriculum as it only provided basic grammar and technical vocabulary. Furthermore, speaking activities and other interactive teaching methods would always depend on the teacher whether he/she has prepared for it in class. There was also no proper model of English speaker as English was not used as medium of instruction. This prompted students the need to have foreign teachers who can teach and use English as a medium of instruction.

Table 3

The comparative significant summary findings of what the students' actually need for their future career and what the present curriculum provides and does not provide

\begin{tabular}{ll}
\hline $\begin{array}{l}\text { What the students actually need (based on what is required of } \\
\text { them as future engineers; Adopted from Salehi, 2010; Singh and } \\
\text { Choo, 2012) }\end{array}$ & $\begin{array}{l}\text { What the curriculum } \\
\text { provides/does not provide }\end{array}$ \\
\hline 1.Ability to communicate in English & Yes \\
\hline 2.Ability to read charts \& tables & No \\
\hline 3.Ability to listen, read, take notes and execute instructions & Yes \\
\hline 4.Ability to plan, manage and lead specific tasks / projects & No \\
\hline 5.Ability to use documents and produce/record documents & No \\
\hline 6.Ability to make presentations and express ideas & No \\
\hline 7.Ability to do research/feasibility study & No \\
\hline 8.Ability to write reports and correspondence & No \\
\hline
\end{tabular}

It can be noted that the present curriculum for Technical English does not provide the necessary skills that are required of the engineering students to become better prepared for their career in the future. For example, reading charts, and tables, planning, managing, and leading specific tasks/projects, using documents and producing/recording documents, making presentations and express ideas, doing research/feasibility study, and writing reports and correspondence. These are important skills that should be included in a technical English curriculum, however, these were not reflected in the present syllabus.

\section{DISCUSSION}

This present study, which looked at the linguistic needs and the language skills of the first year Thai engineering students of KMUTT-Ratchaburi and their implications to the development of an ESP curriculum showed that, student-respondents admitted that having a good command of the English language would mean their success to get a good job and to go abroad. Thus, they recognized the significance of learning English for their future career. They believed that speaking is the most important skill to be developed and should be emphasized more in the EFL classes. It should be noted that English in Thailand is a foreign language and is not widely used as a medium of instruction. Hence, students wanted to improve their speaking skills. Mihalache (2015), Gözüyeşil (2014), Kim (2013), and Petrova (2008) shared the same findings stating that engineering students regarded speaking skills as very important. In fact, the findings of 
Petrova (2008), revealed the importance of various speaking tasks among the employees in Finland which came second in the frequency list of the Estonian and Latvian respondents. This shows that the ability of the students to do presentations, express ideas, and communicate clearly are the skills that the employers look for their employees. According to Butcher (2013) for engineers to become successful, the ability to work with other people from different backgrounds is essential. Thus communication skills is significant for the jobs and honing up these skills in the classroom through a clear curriculum is indeed important.

One of the most important findings from the study is that, student-respondents wanted to be exposed to people who speak English and to the situations where English language is used as a medium of communication. Most of the students revealed that they wanted to go on a field trip, or English camp and talk to foreigners, listen to music, do language games and various interactive activities, watch movies, and use of technology in the classroom. The findings of the studies of Jamal, Harden, Wells, Thomas, and Bonell (2013); Mihalache (2015); Gözüyeşil (2014); Kim (2013); and Nanney (2004) revealed that putting the students into small group activities, exposing them to different interactive activities and other learning materials; speaking practices, vocabulary exercises, and listening activities are important contributing factors for the students' success. Hossain (2013); Midoul (2013); and Salehi (2010) also emphasized in their research findings that engineering students learn better if they are exposed to teaching styles and activities that are interactive, and student-centered. Furthermore, several points from the literature pointed out that through interactive activities, students learn to socialize, collaborate and come up with better ideas as a team. Working as a team is essential in their future career as they are expected to work with groups of people on site or at the office. Thus putting them and giving them group activities in class is already preparing them for their future job. However, these kinds of learning experiences were not practiced in most Thai schools and other EFL classes as English is not used as a language of instruction. Adapting these kinds of learning experiences would help the learners become successful in learning the language (Boroujeni \& Fard, 2013).

Lastly, the findings also revealed that the existing ESP curriculum did not address the linguistic needs and the language skills required of the engineering students to become better prepared for their future career. For example, reading charts, and tables, planning, managing, and leading specific tasks/projects, using documents and producing/recording documents, making presentations and express ideas, doing research/feasibility study, and writing reports and correspondence were not addressed in the ESP curriculum of the university. Therefore, the learning materials and the curriculum must be designed in order to address the learning needs of the students (Qiu, et. al, 2014).

It should be noted that English in the workplace covers a wide range of diverse language skills that the employers are looking for. Singh and Choo (2012) in their study presented the Multidimensional Skills Framework Undergraduate Workplace Skills Inquiry (UWSI) which are required at the workplace and by the employers. These skills, along with the linguistic needs of the students should be addressed in an ESP curriculum. 


\section{IMPLICATIONS}

The results of this study have implications for ESP curriculum designers, classroom ESP teachers, schools' officials, and language policy makers who are working with EFL learners in Thailand and in the ASEAN region to evaluate and assess their existing curriculum and to consider the language needs of the students and the skills they are expected to have for their future careers. By doing so, students would be able to learn effectively, and can also use the language skills they have learned in the classroom to their actual work confidently.

The present study is limited to assessing the needs of the students who are taking the Technical English course in KMUTT- Ratchaburi, and the language skills required of them by their employers for their future job. Due to limited number of respondents and the context involved in the study, the findings may not be a representative of all engineering programs in the country. Therefore, doing a study to different groups of engineering students and to other English curriculum would make a good research.

\section{CONCLUSION}

This present study, which explored the language needs of the first year engineering students and the skills required of them for their future job, highlighted the need to adapt an ESP curriculum where these language needs and language skills are addressed. As findings of this study revealed that engineering students wanted to study English and develop their speaking skills because they wanted to be successful in their future career. It is therefore, a must to consider doing a needs analysis and to take into account the linguistic needs of and the language skills needed by the EFL students in the ASEAN context before designing a curriculum (Soruc, 2012).

Consequently, with this needs analysis conducted, it serves as the basis for the English teachers to get to know more of their students' learning needs, and the policy makers to consider needs analysis of the students before a new learning material is developed.

The study also suggests that future studies need to be carried out where EFL and or ESL for engineering students (and other related disciplines) adopt the features (or at least some of them) that have been identified in this present study; and as being desired by the students. The aim would be to see whether their needs have, indeed, been met. It is also suggested to conduct a tracer study in order to follow up these students into the workplace. The purpose of which is to see how the students cope with the working environment which has a greater demand on their acquired language skills.

\section{REFERENCES}

Bada, E., \& Okan, Z. (2000). Students' language learning preferences. TESL-EJ, 4(3). http://www.tesl-ej.org/ej15/a1.html

Balint, M. (2004). Assessing students' perceived language needs in a needs analysis. In 9th Conference of Pan-Pacific Association of Applied Linguistics, Tokyo. 
Belcher, D. (2006). English for Specific Purposes: Teaching to Perceived Needs and Imagined Futures in Worlds of Work, Study and Everyday Life. TESOL Quarterly, 40,133-153.

Benesch, S. (2001). Critical English for academic purposes: Theory, politics and practice. Mahwah, NJ: Lawrence Erlbaum

Boroujeni, S. A., \& Fateme, M. F. (2013). A needs analysis of English for specific purposes (ESP) course for adoption of communicative language teaching: (A case of Iranian first-year students of educational administration). International Journal of Humanities and Social Science Invention, 2(6), 35-44

Butcher, D. (2013). 5 Must-Have Soft Skills for Engineers' Career Success. http://news.thomasnet.com/IMT/2013/03/18/5-must-have-soft-skills-for- engineerscareer-success. Retrieved March 2, 2016.

Chegeni, N., \& Chegeni, N. (2013). Language Curriculum Development and Importance of Needs Analysis. ELT Voices - India, 3(4). http://eltvoices.in/Volume3/Issue_4/EVI_34_1.pdf

Darasawang, P. (2007). English language teaching and education in Thailand: A decade of change. English in Southeast Asia: Varieties, Literacies and Literatures, Newcastle D. Prescott (Ed) Cambridge Scholars Publishing pp. 187-204.

Dudley-Evans, T., \& St. John, M.J. (1998). Developments in ESP: A multidisciplinary approach. Cambridge, England: Cambridge University Press.

Gözüyeşil, E. (2014). An analysis of engineering students' English language needs. Procedia - Social and Behavioral Sciences 116, 4182-4186.

Hossain, M. J. (2013). ESP Needs analysis for engineering students: A learner centered approach. Journal of PU, 2(2). http://presidency.edu.bd/uploads/Article003.pdf

Hutchinson, T., \& Waters, A. (1987). Needs analysis. English for specific purposes: A learning centred approach. England: Cambridge University Press.

Jamal. F., Fletcher, A., Harden, A., Wells, H., Thomas, J., \& Bonell, C. (2013). The school environment and student health: A systematic review and meta-ethnography of qualitative research. BMC Public Health, 13, 798.

Kaewpet, C. (2009). A framework for investigating learner needs: Needs analysis extended to curriculum development. Journal of Foreign Language Teaching, 6(2),

Kim, H. H. (2013). A research on the english for engineering students course based on needs analysis in Korea. Proceedings, the 3rd InternationalConference on Circuits, 
Control, Communication, Electricity, Electronics, Energy, System, Signal and Simulation. ～http://onlinepresent.org/proceedings/vol25_2013/12.pdf

Lekatompessy, F. M. (2010). Needs Analysis in Curriculum Development. https://upipasca.wordpress.com/2010/02/19/needs-analysis-in-curriculum-development/.

Likert, R. (1932). A technique for the measurement of attitudes. Archives of Psychology, 140, 5-53.

Lin, J., Imbertson, P., \& Moore, T. (2014). Introducing an instructional model for "flipped engineering classrooms"- Part (II): How do group discussions foster meaningful learning? In Proceedings of the 121st ASEE Annual Conference \& Exposition. Indianapolis, IN.

Midoul, M. (2013). Investigating the English Language Needs of Third Year Engineering Students in ESP classes at ENSAM. https://www.academia.edu/5828513/Investigating_the_English_Language_Needs_of_Th ird_Year_Engineering_Students_in_ESP_classes_at_ENSAM

Mihalache, R. (2015). Motivation vs. Need of esp of engineering students. The Journal of International Social Research. http://www.sosyalarastirmalar.com/cilt8/sayi36_pdf/8digersosyalbilimler/mihal ache.pdf

Munby, J. (1978). Communicative syllabus design. Cambridge, England: Cambridge University Press.

Nanney, B. (2004). Student-Centered Learning. http://ollyusofalhaj.ipgkti.edu.my/sumber/resosbestari/PENDEKATAN/scl/7\%20SCLNanney.pdf

Paci, M. (2013). Needs analysis and environment analysis: Designing an ESP curriculum for the students of the Polytechnic University of Tirana. Journal of Educational and Social Research, 3(7) doi:10.5901/jesr.2013.v3n7p425

Petrova, I. (2008). Need analysis as a starting point for designing a syllabus for English for specific purposes course. Master thesis, University of Tartu Department of English Language and Literature.

Qasemi, A. S. (2015). An Investigation of English Language Needs of Engineering Undergraduates at Jawzjan University. Proceedings; International Conference on Language Education and Innovation. http://icsai.org/procarch/1iclei/1iclei-53.pdf

Qiu, X., Dan-ping W., Hau-yee L., \& Ming-tak T. (2014). Needs analysis and curriculum development of vocational Chinese for NCS students. Springerplus 3(Suppl 1): O3. doi: 10.1186/2193-1801-3-S1-O3 
Qualitative Research Consultants Association. (2017). What is Qualitative Research? Retrieved on April 3, 2017. http://www.qrca.org/?page=whatisqualresearch

Salehi, M. (2010). Investigating the English Language Needs of Engineering Students. English for Specific Purposes World, 31(10). http://www.espworld.info/articles_31/needs_analysis_salehi.pdf

Singh, M. K. M., \& Choo, JCS. (2012). Manufacturing Industry Employers' Perception of Graduates' English Language Skills Proficiency. http://dx.doi.org/10.7575/ijalel.v.1n.4p.114

Songhori, M. H. (2008). Introduction to Needs Analysis. English for Specific Purposes world, Issue 4, 2008, www.esp-world.info

Soruc, A. (2012). The Role of Needs Analysis in Language Program Renewal Process. Mevlana International Journal of Education, 2(1), pp. 36-47, 30. http://mije.mevlana.edu.tr/archieve/issue_2_1/4_mije_12_04_volume_2_issue_1_page_ 36_47.pdf

Sothan, S. (2015). Exploring English Language Needs According to Undergraduate Students and Employers in Cambodia. International Journal of Linguistics and Communication, 3(1), pp. 87-96. http://dx.doi.org/10.15640/ijlc.v3n1a11

Takahashi, K., Mynard, J., Noguchi, J., Sakai, A., Thornton, K., \& Yamaguchi, A. (2013). Needs analysis: Investigating students' self-directed learning needs using multiple data sources. Studies in Self-Access Learning Journal, 4(3), 208-218. http://sisaljournal.org/archives/sep13/takahashi_et_al/

UNESCO (2016).

Education.

http://www.unesco.org/new/en/education/themes/strengthening-educationsystems/quality-framework/core-resources/curriculum/ 


\section{Turkish Abstract \\ Tayland Öğrencilerinin Dil İhtiyaçları ve Dil Becerileri: Eğitim Programının Geliştirilmesine Etkileri}

$\mathrm{Bu}$ çalışma, King Mongkut Teknoloji Üniversitesi Thonburi Üniversitesi (KMUTT) Ratchaburi'de bulunan 72 ilk yıl mühendislik öğrencisi, Özel Amaçlara Yönelik İngilizce (ESP) öğretmenleri ve ankete katılan diğer 3 paydaş ile Tayland mühendislik öğrencilerinin dil gereksinimlerini belirlemeyi ve gelecekte bir iş bulmalarını sağlamak için gerekli dil becerilerini geliştirmeyi amaçlamıştır. Çalışmada aynı zamanda öğrencilerin dil gereksinimlerinin ve dil becerilerinin müfredatta ele alınıp işlenmediğini de değerlendirilmiștir. Bu çalışmada kullanılan yöntemler yapılandırılmış görüşmeler, odak grupları ve yarı yapılandırılmış bireysel görüşmelerdir. Elde edilen bulgular öğrencilerin yurtdışına çıkmak ve gelecekteki kariyerlerinde başarılı olmak istediğini ortaya koymuş; böylece, konuşma, geliştirilecek en önemli beceri ve İngilizce derslerinde vurgulanması gereken konulardan biri olarak düşünülmüştür.

Anahtar Kelimeler: EFL öğrencileri, ESP programı, analiz ihtiyaçları, dil ihtiyaçları, dil becerileri

\section{French Abstract \\ Les besoins Linguistiques d'Apprenants thaïs et Compétences linguistiques : Implications pour Développement de Programme d'études}

Cette étude, avec 72 premier an des étudiants d'ingénierie, 3 anglais pour des Buts Spécifiques (EN PARTICULIER) les professeurs de l'Université de Roi Mongkut de Technologie Thonburi (KMUTT) Ratchaburi et 3 autres parties prenantes comme des défendeurs(des personnes interrogées), visés pour identifier les besoins linguistiques des étudiants thaïs d'ingénierie et les compétences linguistiques nécessaires pour eux pour obtenir un travail dans l'avenir. Il a aussi évalué si les besoins linguistiques et les compétences linguistiques exigées des étudiants ont été adressés(abordés) dans le programme d'études. Les méthodes utilisées dans cette étude étaient le questionnaire modifié, des groupes de discussion et ont semi-structuré des entretiens(interviews) individuels. Les découvertes ont révélé que les étudiants ont voulu aller à l'étranger et avoir du succès dans leurs carrières futures; ainsi, la conversation considérée comme l'habileté(la compétence) la plus importante à être développée et devrait être soulignée dans leurs classes anglaises.

Mots Clés: EFL des apprenants, EN PARTICULIER le programme d'études, a besoin de l'analyse, des besoins linguistiques, des compétences linguistiques 
Arabic Abstract

الاحتياجات اللغوية للمتعمين التايلانديين والمهارات اللغوية: الآثار المترتبة على تطوير المناهج الدراسية

تهدف هذه الدر اسة، التي تضم 72 طالبا في الهندسة في السنة الأولى، و 3 من معلمي اللغة الإنجليزية لأغراض اضلئ معينة (ESP)

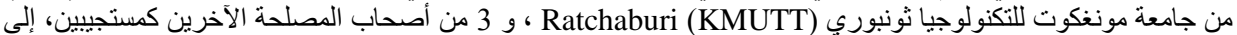

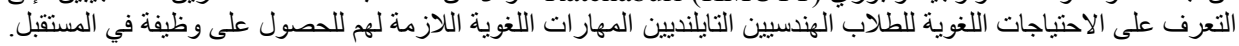

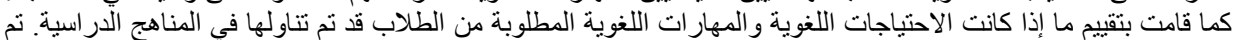

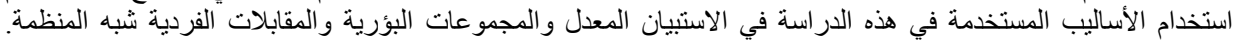

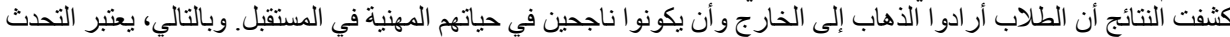

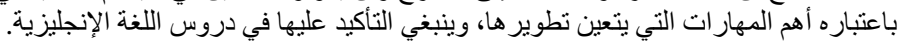

الكلمات الرئيسية: المنعلمين إفل، والمناهج إسب، وتحليل الاحتباجات، والاحتباجات اللغوية، و المهار ات اللغوية

German Abstract

Thailändische Lernende Linguistische Bedürfnisse und Sprachkenntnisse: Implikationen für die Curriculumentwicklung

Diese Studie, mit 72 ersten Jahr Ingenieurstudenten, 3 Englisch für spezifische Zwecke (ESZ) Lehrer der King Mongkut University of Technology Thonburi (KMUTT) Ratchaburi, und 3 anderen Stakeholder als Befragten, zielte darauf $a b$, die thailändischen Ingenieurstudenten linguistischen Bedürfnisse und die Sprachkenntnisse für sie, um einen Job in der Zukunft zu bekommen. Es wurde auch beurteilt, ob die sprachlichen Bedürfnisse und die Sprachkenntnisse der Studierenden im Curriculum angesprochen wurden. Methoden, die in dieser Studie verwendet wurden, wurden modellierte Fragebogen, Fokusgruppen und halbstrukturierte Einzelinterviews. Die Ergebnisse zeigten, dass die Studierenden ins Ausland gehen und in ihren zukünftigen Karrieren erfolgreich sein wollten. also in Betracht gezogen, als die wichtigste Fähigkeit zu entwickeln und sollte in ihren englischen Klassen betont werden.

Schlüsselwörter: EFL-lernende, ESZ-curriculum, bedarfsanalyse, sprachliche bedürfnisse, sprachkenntnisse 


\section{Malaysian Abstract \\ Kemahiran dan Keperluan Bahasa Pelajar Thai : Implikasi untuk Pembangunan Kurikulum}

Kajian ini dengan 72 orang pelajar kejuruteraan tahun pertama, 3 orang guru Bahasa Inggeris untuk Tujuan Khusus (ESP) dari Universiti Teknologi King Mongkut Thonburi (KMUTT) Ratchaburi, dan 3 pihak berkepentingan lain sebagai responden yang bertujuan untuk mengenal pasti keperluan linguistik pelajar kejuruteraan Thai kemahiran bahasa yang diperlukan untuk mereka mendapatkan pekerjaan di masa depan. Ia juga menilai sama ada keperluan linguistik dan kemahiran bahasa yang diperlukan oleh pelajar ditangani dalam kurikulum. Kaedah yang digunakan dalam kajian ini adalah soal selidik yang diubahsuai, kumpulan fokus dan wawancara individu separuh berstruktur. Penemuan mendedahkan bahawa pelajar mahu pergi ke luar negara dan berjaya dalam karier masa depan mereka; Oleh itu, dianggap sebagai berkata sebagai kemahiran yang paling penting untuk dikembangkan dan harus ditekankan dalam kelas bahasa Inggeris mereka.

Kata Kunci: pelajar EFL, kurikulum ESP, analisis keperluan, keperluan linguistik, kemahiran bahasa

\section{Russian Abstract \\ Лингвистические Потребности и Языковые Навыки Тайских Учеников: Последствия для Разработки Учебной Программы}

Это исследование, в котором принимали участие 72 студента-инженера 1 курса, 3 преподавателя английского языка для специальных целей Технологического университета Кинга Монгкута Тонбури Ратчабури и 3 других заинтересованных лиц в качестве респондентов, направленное на выявление языковых потребностей тайских инженерных студентов и языковых навыков, необходимых им для получения работы в будущем. Это исследование также помогла выяснить, были ли лингвистические потребности и языковые навыки, необходимые для учащихся, рассмотрены в учебной программе. Методами, используемыми в этом исследовании, были модифицированная анкета, фокус-группы и полуструктурированные индивидуальные интервью. Выводы показали, что студенты хотели уехать за границу и быть успешными в своей будущей карьере; таким образом, умение корректно разговаривать является самым важным навыком, который должен быть разработан и должен быть подчеркнут в их английских классах.

Ключевые Слова: ученики EFL, учебная программа ESP, анализ потребностей, лингвистические потребности, языковые навыки 